\title{
Valuing Reciprocal Synergies in Merger and Acquisition Deals Using the Real Option Analysis
}

\author{
Andrejs Čirjevskis \\ Business Department, RISEBA University of Applied Sciences in Business, Arts, and Technology, LV-1048 Riga, \\ Latvia; andrejs.cirjevskis@riseba.lv
}

Received: 1 March 2020; Accepted: 24 April 2020; Published: 30 April 2020

\begin{abstract}
This research explores how global cosmetic players sense emerging market demand for new technologies and products, seize opportunities through the acquisition of core competencies that they needed, and transform their global value chain. The aim of this paper to assess the prerequisites of reciprocal synergies in merger and acquisition (M\&A) deals pursuing global growth. To achieve this aim, the author asked a research question: what is the best way to measure the competence-based synergies as added market value in M\&A deals? To answer this question, the author researched the latest theoretical findings on the antecedents of synergy in the merger and acquisition processes. The valuation of reciprocal synergies with real options was discussed with a focus on input variables' values. Based on in-depth content analysis, the ARCTIC (A-Advantage, R-Relatedness, C-Complexity of Competence, T-Time of Integration, I-Implementation Plan, C - Cultural Fit) framework was developed and tested. The author selected three case studies to test the methodology empirically, namely, L'Oréal's Body Shop acquisition in 2006 and divestiture in 2017, the acquisition of The Body Shop by Brazilian's Natura Group in 2017, and the acquisition of Avon Products by Natura that was announced in 2019. The model for the valuation of reciprocal synergies used and discussed real options with a special focus on input variables' values.
\end{abstract}

Keywords: acquisitions; core competence; knowledge transfer; synergy; real options

\section{Introduction: Purpose and Research Question}

The authors of the core competence theory (Prahalad and Hamel 1990) argue that the difference in performance between the two firms is because one focused on core competencies while the other focused on business. The core competence of the corporation is "a combination of complementary skills and knowledge bases embedded in a group or team that results in the ability to execute one or more critical processes to a world-class standard" (Coyne et al. 1997, p. 43). Core competence is one of the most promising sources of a sustainable advantage (Coff 2002) and is, therefore, a logical focus in acquisitions as a source of synergy (Čirjevskis 2015). However, the relatedness of different sets of core competencies and their transferability in merger and acquisition (M\&A) processes have been largely overlooked in the extant literature on international M\&A deals (Alhenawi and Stilwell 2018; Alhenawi and Krishnaswami 2015; Andrade et al. 2001). Alhenawi and Krishnaswami (2015, p. 93) argue “... that the lack of synergies from market power enhancements and capital market activity in related mergers is consistent with related mergers being motivated by a need for facilitating technology and innovation transfers rather than generating synergies".

This paper aims to assess the prerequisites of competence-based (reciprocal) synergies in the M\&A deal pursuing global growth. The current research seeks antecedents of the competence-based synergies in M\&A deals and modes to apply real options theory (ROT) as a way to value those synergies. Within this approach, the author introduces the combination of the core competence theory and the real 
options theory in the international M\&A deals' context, offering a research agenda for future research. In addition, this paper provides a major theoretical and empirical contribution to this research area.

Chi et al. (2019, p. 525) suggested exploring an area where ROT can be combined with other theoretical perspectives to better understand international business phenomena. In their research, the authors argue that the integration of core competence theory with ROT advances and contributes to theoretical and empirical development in international business (IB) and strategic management. What is more, existing empirical studies on multinational enterprises (MNE) based on ROT typically focus on the perspective of a single firm (Chi et al. 2019), except for a very small number of analyses that examine JV formation and M\&A deals (Chi 2000; Chi and Seth 2009; Li et al. 2008). Having provided the ARCTIC framework to predict competence-based (reciprocal) synergies in M\&A processes and to measure a reciprocal synergy with real options, the current paper contributes to theoretical and practical issues of global M\&As as part of the existing literature of international business and strategic management.

The ARCTIC framework can be used as a preliminary evaluation of core competencies and as a source of synergy. The ARCTIC framework (A-Advantage, R-Relatedness, C-Complexity of Competence, T-Time of Integration, I-Implementation Plan, C-Cultural Fit) was developed by Chirjevskis and Joffe (2007) to assess similarities, complementarities, and compatibility of core competences of the collaborative partners as sources of synergy in M\&A deals. The ARCTIC framework was successfully tested using the research of two inductive case studies, namely a successful cooperative deal involving Ford and Mazda when Ford had increased its stake in Mazda to 33.4\% in 1996, and one of the biggest acquisitions in the telecommunication industry which was documented as being financially disastrous: AT\&T's takeover of NCR in 1991.

Using the ARCTIC research framework is similar to using the four criteria (questions) of the VRIO framework (Barney 1996). The first three criteria of the ARCTIC framework measure the extent to which core competencies are valuable (V) to customers (external relatedness) and rare (R) and difficult to imitate (I) for competitors (internal advantages), as well as the absorptive capacity of external core competencies provided by an acquirer's and target's companies (complexity). The next three criteria are more concerned with the integration process of core competencies and the organization $(\mathrm{O})$ of core competence transfer in the M\&A process.

The first published paper (Chirjevskis and Joffe 2007) on this topic failed to answer an important question: can the ARCTIC framework predict operational, financial, or managerial types of synergy? There are multiple types of synergies including cost reduction (delete redundancies, economies of scale), revenue increase (cross-selling), and managerial synergies. Understanding the differences between these was a critical point for further development of the ARCTIC framework. Having adopted Dyer et al.'s (2004) research framework on the type of managerial synergies (modular, sequential, or reciprocal), the ARCTIC framework was extended and empirically tested again (Čirjevskis 2015). The case study research of Facebook's acquisition of WhatsApp (Čirjevskis 2015) had justified logical conjunction of the ARCTIC framework with Dyer et al.'s (2004) framework.

However, Dyer et al.'s research was criticized for stating that the ARCTIC framework provided an analysis of the M\&A deal where all six factors were satisfied (Čirjevskis 2015). In this context, it would be immensely helpful to present case studies that offer some contrast with these claims. This current paper provides new analyses of recent acquisitions where the ARCTIC framework was satisfied and where the ARCTIC model was NOT satisfied. This allows readers to contrast case studies and grasp how the framework works in greater detail. Moreover, this research shows that the synergy potential of M\&A deals can often be approximated by the premium paid to obtain the new company. As a result, the research addresses the question of how to measure the competence-based synergies as forms of market added-value in M\&A deals predicted by the ARCTIC framework. The author argues that a potential competence-based synergy can be approximated by using the real options theory (ROT).

The paper is organized as follows. In the beginning, it explores the nature of synergies in M\&A deals and discusses opportunities to value reciprocal synergies as a real option. Based on an in-depth 
literature review, the ARCTIC framework is developed. To contribute an interdisciplinary approach to predict synergy of M\&A using the ARCTIC framework and to value synergies as real options, the paper provides empirical research bridging ROT and core competence theory in a holistic synthesized view. The author selected three inductive (illustrative) case studies of the most successful cosmetic industry giants and their most intriguing M\&A deals—specifically, L'Oréal's acquisition (2006) and divestiture of The Body Shop (Butler 2017), and the acquisitions of The Body Shop (Butler 2017) and Avon Products Inc. (CISION 2019) by the Brazilian company Natura Cosméticos S.A. L'Oreal is the No.1 beauty company in the cosmetics industry, and has annual beauty product sales of over USD 29.4 billion. (Straits Research 2020, p. 1). Having completed an acquisition of Avon Products, Natura \& Co has created the world's fourth-largest pure-play beauty group with an annual gross revenue of over USD 10 billion (CISION 2020). These cases were selected to test the developed ARCTIC framework empirically. The model for the valuation competence-based synergies using real options application is discussed with a special focus on input variables' values. At the end of the paper, the author discusses empirical and theoretical findings, limitations, and future work.

\section{Existing Frameworks}

The classic method used in academic research is to read the literature on a topic of interest and identify any gaps in previous studies, since these gaps indicate opportunities for future research (Collis and Hussy 2009). This literature review illuminates the current research and gaps in the literature. Finally, the literature review develops a theoretical framework of current research that leads to a new research question.

\subsection{Resources, Capabilities and Core Competencies: The VRIO Framework}

The theoretical foundation of the current paper is Penrose's intellectual contribution to resource-based competitive advantage. The roots of resource-based theory come from Penrose (1959), whose theory of firm growth viewed organizations as bundles of resources, administered by a certain network of individuals and groups. As Rugman and Verbeke maintain: "The theory of the growth of the firm is considered by many scholars in the strategy field to be the seminal work that provided the intellectual foundations for the modern, resource-based theory of the firm" (Rugman and Verbeke 2002, p. 769). Resources are the source of firm capabilities. Capabilities, in turn, are the source of a firm's core competencies, which are the basis of competitive advantages (De Carolis 2003). Later studies of the 1990s gave way to modern resource-based firm theories, namely, Barney's (1996) VRIO framework for the analysis of resources, capabilities, and core competencies.

The VRIO framework aims to evaluate whether or not resources and capabilities were likely to be a source of core competence and, thus, a source of sustained competitive advantage. This evaluation is based on the answers to four questions. The first is whether a M\&A deal can provide a competence that is valuable for respond to environmental opportunities or threats. Providing a customer value proposition beyond what competitors offer is the most obvious evidence of a company's value. Second, does a firm possess unique and rare resources and capabilities that a developed strategy can utilize? A firm should not expect to gain advantages from these resources and capabilities if they are not rare. On the other hand, valuable and rare resources and capabilities can be a source of at least a temporary advantage. Third, how long will it take other firms to imitate your resources and capabilities? If competences (which are quantities of resources and capabilities) are hard to imitate, then they are more likely to be a source of longer-lasting competitive advantages. The fourth question focuses on an organization-is a firm organized to execute and protect its sources of advantages or not? According to Barney (1996), organizational issues like a firm's reporting structure, management controls, and incentives enable a firm to realize the full potential of its competences.

The current paper argues that it is not enough to identify the core competencies of an acquisition and a target. The core competences transfer to obtain synergy is much more complex than the organization of a reporting structure and management control systems. Scholars should dig deeper 
to provide an answer to the fourth Barney question: how should we organize $(\mathrm{O})$ competence-based synergies in the context of the international M\&A process? The core competences should be investigated through the lens of a question: do they work together and provide a form of synergy? To answer the research question, the ARCTIC framework for competence-based synergy evaluation in M\&As was developed. This idea is consistent with core competence theory (Prahalad and Hamel 1990) and with different views on the sources of competitive advantages, namely, the resource-based view (RBV) (Penrose 1959; Barney 1996), knowledge-based view (KBV) (Grant 1996), and dynamic capabilities view (DCV) (Teece et al. 1997). In summary, an application of the ARCTIC framework helps to predict competence-based synergies in M\&A processes.

\subsection{Competence-Based Synergy Testing in MEAs with the ARCTIC Research Framework: An Approach}

The first three criteria of the ARCTIC framework assess similarities and complementarity of core competencies in a newly merging organization and they are very similar to the first three criteria of the VRIO framework. The first three criteria also correspond with Penrose's (1959) and Rugman and Verbeke's (2002) argumentation that "competences lead to sustained superior returns, to the extent that they are firm-specific (i.e., imperfectly mobile), valuable to customers, non-substitutable and difficult to imitate" (Rugman and Verbeke 2002, p. 770).

The next three criteria also correspond with the argument by Penrose (1959) that the limits to inorganic growth through M\&As are set by the conflict between the speed of expansion (in the current research, this is the time needed for integration) and the maintenance of efficient coordination (in the current research, this is the implementation plan and cultural fit) (Penrose and Pitelis 2009). Therefore, the author has justified the reason to include or to exclude relevant criteria in the ARCTIC framework by their correspondence to Penrose's theory and the resource-based view of Barney on sustained competitive advantages.

To create a reciprocal synergy in M\&A deals, the core competences of both companies should satisfy all six critical success factors. Of course, each criterion, given in question form, should be explained at length:

A-Internal Advantage-Are core competencies of the target company rare and difficult to imitate? In other words, do the core competences of one company (the target company) need to be further developed to promote complementarity (Hitt et al. 2009; Bauer and Matzler 2014) and to provide

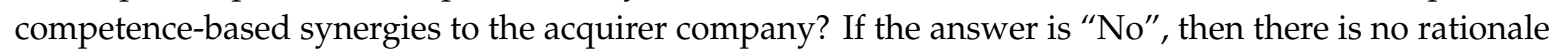
behind the merger. If the answer is "Yes", then competence is rare and difficult to imitate for many competitors. This is the first factor of the synergy potential of a transaction.

$\mathrm{R}$-External Relatedness or Relevance-Do core competences of one company bring value to the other company that strongly depends on the external opportunity and environment in which the competence will be used? If the competence is idiosyncratic and creates internal advantages but is not externally related to market demand and does not support a new customer value proposition, then the answer is "No". If the core competencies enable the companies to respond to environmental opportunities or threats (Barney 1996; Bauer and Matzler 2014) and underpin a new customer value proposition, then the answer is "Yes". This is the second factor of the synergy potential of a transaction.

C-Complexity of core competences. Having core competencies that are advantageous, valuable, and relevant for the other company is important, but it might be not enough. If competence is based on complex technologies and sophisticated know-how, it would be difficult for the other company to absorb and exploit. The answer to the complexity question is "No" if core competencies are complex and inappropriate for fast absorption by the other company (Hitt et al. 2009; Bauer and Matzler 2014); this would hamper competence-based synergy. If the appropriation of core competences by the other company is not very timely or costly and they are quite easy to absorb and exploit, then the answer is "Yes". This is the third factor for the reciprocal synergy in M\&A deals.

T-Time of integration. The time or speed of the knowledge-sharing process and integration of core competencies may be a very important factor for successful acquisitions in generating synergy. 
The question is as follows: are the acquisition process and post-acquisition merger as well as the process integration of two sets of different core competencies into a cohesive whole time-consuming or not? If valuable and rare core competencies take time to absorb, then the answer is "No". Thus, if core competencies' transfers take a relatively short time (Netz et al. 2019; Spanner et al. 1993) when fast strategic decision making is involved, then the answer for this criterion is "Yes". This is the fourth factor of the synergy potential of the M\&A process.

I-Post-merger integration plan for core competencies. The topic of post-merger integration is highly complex and has to be planned in considerable detail, as well as effectively and efficiently executed (Hitt et al. 2009; Bauer and Matzler 2014). If the acquirer has a focused plan that everyone understands and believes in, then the answer is "Yes". The answer is "No" if there is no integration plan. This is the fifth factor of the synergy potential of the M\&A process.

C-Cultural fit of core competences. If the top management team and staff of the organizations will support and reflect the new organizational culture (Cartwright and Schoenberg 2006; Bijlsma-Frankema 2001; Lodorfos and Boateng 2006; Nguyen and Kleiner 2003) then the answer for this criterion is "Yes". However, if there is cultural incompatibility, then the answer is "No". This is the sixth factor for the synergy potential of the M\&A process.

To summarize synergies in M\&A are fostered by the internal advantages (A) and external relevance $(\mathrm{R})$ of core competencies to internal and external settings, the complexity $(\mathrm{C})$ of absorbing core competencies by merging companies, the degree and speed of integration of both companies into a cohesive whole or time (T), the post-merger implementation plan of integration (I), and cultural fit (C) (Chirjevskis and Joffe 2007; Čirjevskis 2015).

\subsection{Exploring Competence-Based Synergy Potential in Strategic Transactions: Dyer, Kale, and Singh's Framework}

"Every time one company launches a takeover bid for another, the justification is always about synergies ... But this" sum of synergies" approach to evaluating deals is highly problematic" (Zenger 2016, p. 2). Dyer et al. (2004) defined three different types of synergies: Sequential synergies, modular synergies, and reciprocal synergies. Authors argue that the type of synergies sought depends on the type of collaborative strategies (alliance, equity acquisition, full acquisition), nature of resources, the extent of redundant resources, the degree of market uncertainty, and the level of competition.

First, partners seek modular synergies when they manage resources independently and when pooling results together with others for increased profit (Dyer et al. 2004). For example, American retailing giant Walmart is partnering with IBM to bring in traceability and transparency to its entire food supply network using blockchain. Walmart opened a Walmart Food Safety Collaboration Center in Beijing in 2016, a collaboration between Walmart, IBM, and Tsinghua University to improve the way that food is tracked, transported, and sold to consumers across China. Then, in 2017, a group of leading companies across the global food supply chain announced a major blockchain collaboration with IBM intended to further strengthen consumer confidence in the global food system (Lawrence 2018). The partnerships with technologically advanced giants are underpinned by modularly interdependent soft resources and give giant food store capabilities to expand into new channels and markets.

"Second, firms derive sequential synergies when one company completes its tasks and passes on the result to a partner to do its bit. In those cases, the resources of the two firms are sequentially interdependent" (Dyer et al. 2004, p. 5). On 16 June 2017, Amazon acquired Whole Foods in a US\$13.7 billion all-cash transaction. Post-acquisition, Whole Foods continued to operate stores under the Whole Foods Market brand. To be successful in the offline retail food segment and own-brand grocery stores, Amazon needs to have knowledge of traditional retailing and an effective supply chain management process for both factories and retail stores (HBS 2017). Amazon has good supply chain management in a warehouse for online retail orders, but now Amazon is more certain of whether this experience is transferable to an offline retail store. Whole Foods is an attractive platform for Amazon to engage in 
the transformation of an industry. Amazon also can help Whole Foods to buy high-quality products more cost-effectively and thus improve gross margins while keeping customers satisfied. As a result, Amazon can change their cost structure as well as potentially increase revenue streams for mobile professional users and this can result in sequential synergies.

Reciprocal synergies are when reciprocally inter-dependent resources generate synergies (Dyer et al. 2004). For instance, Instagram, a popular photo-sharing app, was acquired by Facebook in 2012. Instagram was specially designed to be used on smartphones. In comparison to this, Facebook had a growing challenge to transfer its platform to a mobile application. One of the reasons for its failure was high complexity (Sharma 2016). Due to Instagram's sustained advantages-a mobile-focused application and its high quality and simplicity-it became possible for Facebook to successfully face their challenge. They could come up with a variety of exceptional knowledge and important technological experiences in the ICT business. Therefore, the strategy of buying companies to obtain the knowledge of their people would build a reciprocal synergy involving Instagram (both firms execute tasks through close knowledge sharing). By combining the high frequency of photo sharing on both platforms, Facebook could raise its number of users even more.

Thus, Dyer et al.'s research shows that executives must analyze three sets of factors before deciding on a collaboration option: synergies and the resources they desire, the marketplace they compete in, and their capabilities and core competencies at collaborating (Dyer et al. 2004). To sum up the sub-chapter, competence-based synergies in M\&A deals are a reciprocal type of synergies provided by inter-dependent core competences of an acquirer and their target.

\subsection{Measuring Competence-Based Synergies in MEA with a Real Option: Dunis E Klein Approach}

A real option is a right, free of any obligation, to undertake a specific future action at some cost concerning expanding existing production facilities or acquiring a partner's ownership stake (Chi et al. 2019). This paper incorporates the application of real options into synergy evaluations arising from M\&A processes (Loukianova et al. 2017). When it comes to option variables used to value a type of synergy, my research has employed Dunis and Klein (2005, p. 8)'s relevant recommendations.

The price of the underlying asset $(S t)$ is the cumulated market value of the target and acquirer before the announcement (four-week average) has to be taken by excluding the week of the announcement. The announcement day is taken from the Financial Times and confirmed by local newspapers or the Internet. To avoid effects from early information leakage, the previous four-week average of share prices excluding the week of the announcement has to be used (Dunis and Klein 2005, p. 7). Data on market capitalization are usually available on the https:/www.reuters.com/, and other available sources.

The strike price of the option $(K)$ is the hypothetical future market value of the separated entities; a forecast of the strike price can be obtained using multiples analyses (EBITDA, revenue, etc.) and/or with discounted free cash flow forecasts (Dunis and Klein 2005).

The standard deviation $(\sigma)$ is the annualized standard deviation of weekly returns after a merger occurs. "Assuming semi-efficient markets that incorporate publicly available new information promptly, the calculation of the standard deviation of the acquirer stock price return was started the week after the announcement" (Dunis and Klein 2005, p. 7). The volatility $(\sigma)$ of share price can be obtained from the V-Lab APARCH Volatility Analysis (NYU Stern 2019) or through direct observation.

Time in years $(t)$ is a managerial assumption on the number of years when competence-based synergy will be realized. Dunis and Klein assumed one year for the time to maturity (2005, p. 7). This was due to the assumption that efficient markets should have anticipated potential long-term merger gains within this time, even if accounting data might not reflect any benefits in this short period due to integration costs. However, due to data availability, the current research has obtained elements of a company's reciprocal synergy from the prospectus on mergers developed by the acquirer's company.

For the risk-free rate (Rf), the domestic three-month rate of the acquirer's country on the announcement day was used. The risk-free rate (Rf) is a long-term government bond yield (Dunis and Klein 2005) and can be taken from WorldGovernmentBond. 
The European option allows execution-only on the day of expiration and thus can be used to value a form of synergy only when competence-based synergies would be fully realized. An American option allows holders to exercise their option rights at any time before and including the day of expiration and, as a result, an American option allows for valuing a competence-based synergy step-by-step within the forecasted time frame by using time steps. To sum up this sub-chapter, the valuation of synergy obtained by employing real options theory illuminates to executives the competence-based synergism of M\&A deals.

To conclude this chapter, the exploration of the relationships within the existing framework (VRIO, ARCTIC, the frame of Dyer et al., and Real Option) provides the foundations for developing a comprehensive theoretical framework based on which this paper's research question can be answered.

\section{Research Design and Methodology}

This article combines research from the first part of 2018 with a newer empirical study from the latter part of 2019. The research (Čirjevskis 2019) investigated the empirical evidence of competence-based synergy in the global information and communication technology industry (Facebook's acquisition of Instagram in 2012, Facebook's acquisition of WhatsApp in 2014, Microsoft's acquisition of LinkedIn in 2016), and the cosmetics industry (L'Oréal's acquisition of The Body Shop in 2006 and its divestiture in 2017). The global cosmetics and ICT industries were selected because of their global nature and due to major and complex changes to their competitive environments. This focus helps to explore the competencies and knowledge transfer known as being the main drivers of the successful acquisition process. To examine the validity of previous findings and to further test the ARCTIC framework's methodology, newer case studies were conducted in the autumn of 2019 concerning Brazilian Natura \& Co's acquisition of The Body Shop and the acquisition of Avon Products, Inc. (Čirjevskis 2020). Newer empirical studies explored the applicability of the ROT to measure a competence-based synergy as added market value in an M\&A deal.

\section{The Theoretical Framework of the Research}

A theory is an "explanation of how things function or why an event occurs" (Black 1993, p. 25). A theoretical framework is a collection of theories and models from the literature which underpins a positivist study (Collis and Hussy 2009). Such a theory is a fundamental part of the research studies and underpins research questions. The author asked a research question: what is the best way to measure competence-based synergies as market added-value in M\&A deals? To answer this question, the author has designed the theoretical framework of the research, given in Figure 1. This framework involves two stages of research. The first stage is inductive case studies. Yin defines the case study research method as "an empirical inquiry that investigates a contemporary phenomenon within its real-life context; when the boundaries between phenomenon and context are not evident; and in which multiple sources of evidence are used (Yin 1984, p. 23)". It is a major advantage of case study research that the few chosen samples (four case studies in the current research) can be investigated in-depth, which would not be possible with a large case sample (Yin 2009).

Regarding the presentation of evidence, due to the rich amount of data that accumulates during case studies, Eisenhardt and Graebner state that there is no strict norm similar to that applied in large-scale studies when presenting results (Eisenhardt and Graebner 2007). Therefore, the second stage of the current research involves a demonstration of the application process of the ARCTIC framework by using the outcomes of three inductive (illustrative) case studies and literature research. 


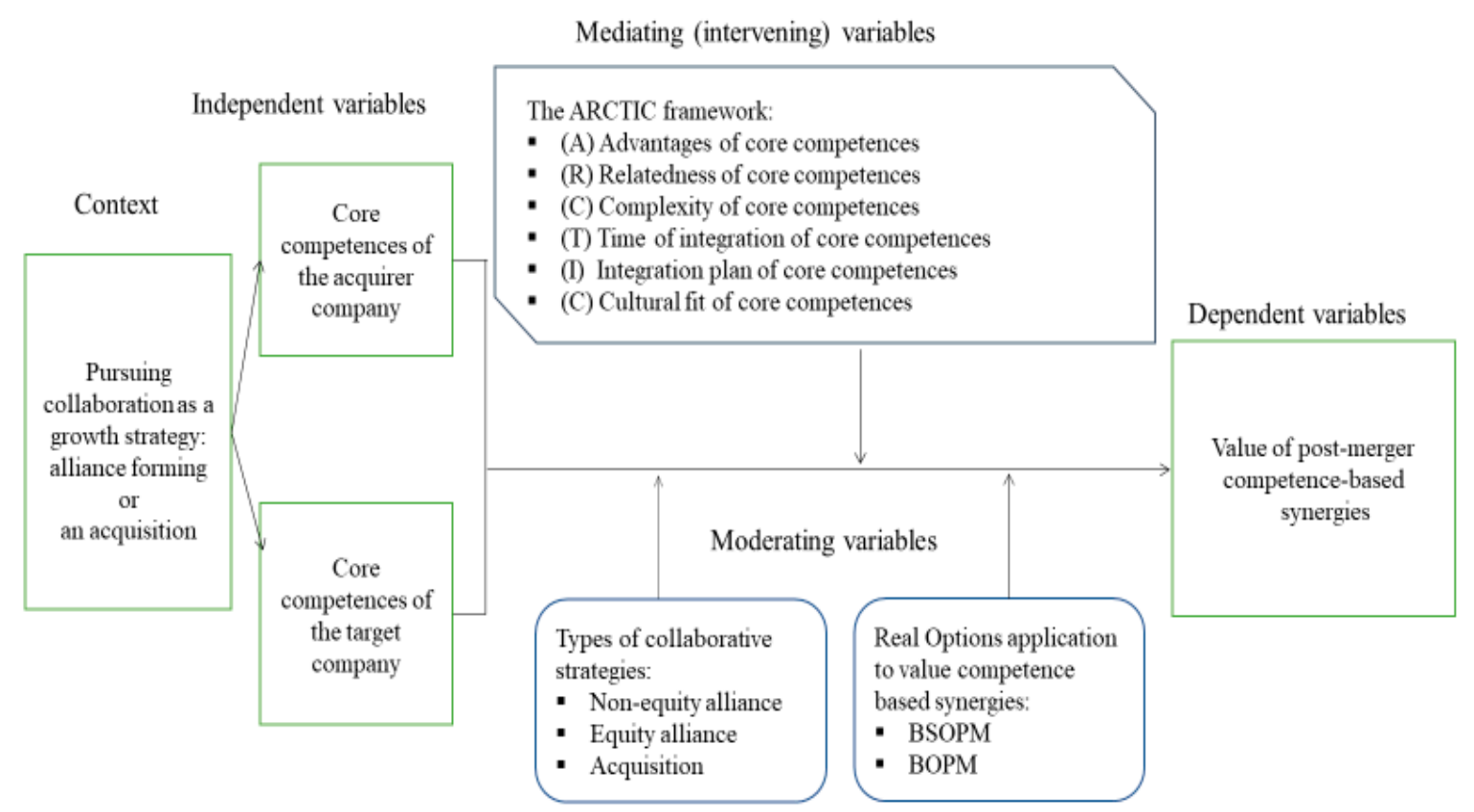

Figure 1. The theoretical framework of the current research.

In the current research, the core competences of the acquirer and target companies are independent variables. The type of collaborative strategy is the moderating variable. A real option valuation with which to value competence-based synergies in M\&A is the moderating variable. The moderating variable has a strong contingent effect on the independent variable-dependent variable relationship (Sekaran and Bougie 2018). The ARCTIC framework's six critical success factors are mediating variables. The mediating variable (or intervening variable) surfaces between the time the independent variables start operating to influence the dependent variable and the time their impact is felt on the dependent variable (Sekaran and Bougie 2018). The value of post-merger competence-based synergies is the dependent variable of the current research.

Even though strategy-as-practice or process-based approaches in empirical qualitative research usually have an element of ethnographic or discursive analysis using primary data (sometimes in addition to secondary data, sometimes alone), the study of the ARCTIC framework's six critical factors is challenging because they are often tied to a set of variables such as innovative technologies, organizational culture, etc. Regarding the current research, the author did not interview executives of companies due to the availability of actual interviews, reports, and companies' documents as secondary data sources.

Contextual positioning is a tool that can be used to prepare extant data for analysis. To apply the ARCTIC framework to assess prerequisites of the M\&A success, the author adopted the contextual positioning method (Ralph et al. 2014) by using the secondary data of three inductive case studies and relevant documents as extant data in grounded theory research. A central idea of content analysis is that "many words of text can be classified into much fewer content categories" (Weber 1990, p. 7). Content analysis is a qualitative research method that uses a set of procedures to classify or otherwise categorize communications (Weber 1990). By typically relying on archival data to extract criteria of interest to strategic management scholars, content analysis has aided in analyzing corporate strategies (Bowman 1978), strategic groups (Osborne et al. 2001), and joint ventures (Merchant 2004). Any source of communication such as shareholder letters, interview narratives, speeches, or transcripts from recorded meetings of executives or even job adverts could be used by a strategy researcher as an effective data source for content analysis. It provides a good match theoretically between the information being assessed (how information is being content analyzed) and the context from which it is drawn (does the type of text being used as a source of content analysis data fit the research question?). 
There are three main sources of information that have been used in the research: scholars' research and publication, news media, and company reports. The author read and codified the content of research articles, cases, and videos on the L'Oréal strategy with The Body Shop, and the Natura Cosméticos strategy with The Body Shop and Avon. By positioning the extant data of inductive case studies using contextual positioning, the author has identified the key success factors of competence-based synergy and codified them in the ARCTIC framework, locating core competences of the acquirer and target companies within the appropriate factors of ARCTIC and explaining their role in the generation of competence-based synergy in M\&A. Therefore, contextual positioning enhanced the interactivity of the data collection process as follows:

The first step is to identify the core competencies of an acquirer's and a target's companies. Using the VRIO framework, the resources and capabilities of an acquirer's and target's companies can be evaluated in terms of their value, rareness, imitability, and organization. Therefore, the VRIO framework allows for identifying core competencies of merging companies as a source of their sustained competitive advantages.

The second step is to apply the ARCTIC framework to predict a potential competence-based synergy in M\&A. Using the ARCTIC framework, core competencies of both companies (an acquirer and a target) can be analyzed in terms of their compatibility, complementarity, and transferability to generate a competence-based synergy of the merging company. Using the ARCTIC framework, core competencies of a target company can be analyzed by an acquirer company in terms of their complementarity (A, R), compatibility (C), and transferability (T, I, C) by giving the answers "Yes" or "No". Then core competencies of an acquirer company are analyzed in the same manner for the target.

The third step is defining the type of competence-based synergy that both companies would obtain. The third step is defining the recommended type of collaborated strategy and a type of competence-based synergy that both companies would obtain. By using Dyer et al.'s framework, a type of potential competence-based synergy (modular, sequential, or reciprocal) is identified.

The fourth step is valuing reciprocal synergies in M\&A with a real option application. The competence-based synergies in the M\&A deal are measured as added market value using real options application involving Black-Scholes Option Pricing Model (BSOPM) and the Binominal Option pricing model (BOPM).

Evaluating the intercoder reliability of a coding frame is frequently recommended as being good practice in qualitative analysis ( $\mathrm{O}^{\prime} \mathrm{C}$ onnor and Joffe 2020, p. 1). However, the author argues that it is an unnecessary step within the goals of the qualitative analysis of this paper. The same secondary data for case studies have been analyzed four times from different perspectives during the four steps used by the current research by using four frameworks to identify prerequisites of competence-based synergies in M\&A deals, as shown in Figure 2. Thus, this proves the systematicity and transparency of the coding process and helps to convince the reader of the trustworthiness of the analysis $\left(\mathrm{O}^{\prime} \mathrm{Connor}\right.$ and Joffe 2020).

Inductive research that uses a case as its inspiration might start with the case and then focuses on the theory (Siggelkow 2007). In contrast, this paper employs cases as an illustration and then presents cases after the theory, which is more useful in inductive research (Siggelkow 2007). A contextualized explanation is a case-study methodology through which a theory can be developed and tested (Tsang 2013). Most strategy research addresses "why" questions. The methodology of contextualized explanation is ideal for inductive research looking for answers to "how" questions in strategy research (Dagnino and Cinici 2016). This paper explains "how" synergies can be realized in mergers and acquisitions, as shown in Figure 2. 


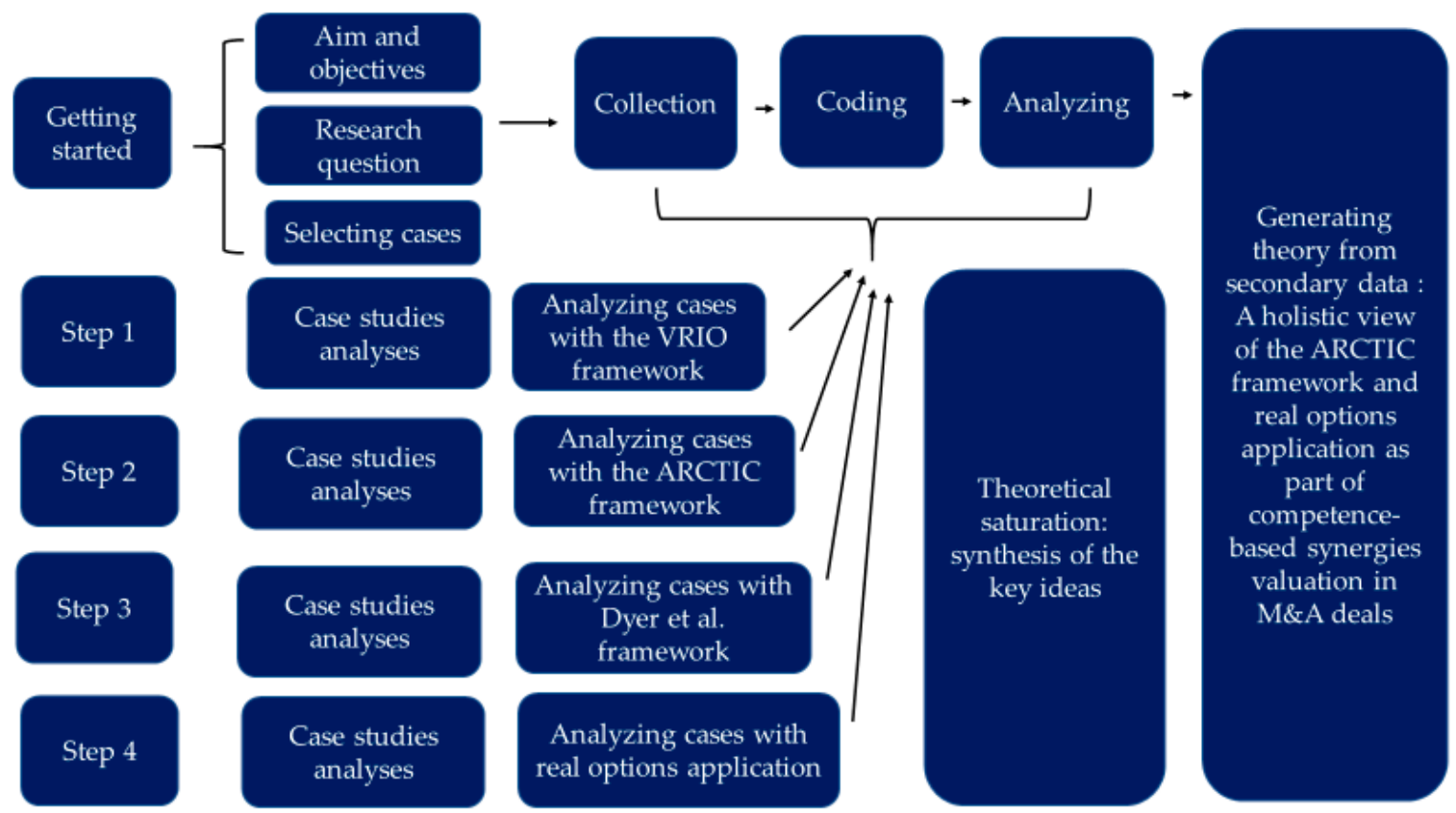

Figure 2. Creating theory from secondary data: the case studies process of the current paper, adapted from Arzuaga et al. (2014) and extended by the author.

The first step is to identify anchors that allow the key data to be gathered. Thus, the initial coding scheme can be derived from the theoretical frameworks (VRIO, ARCTIC, and Dyer et al.). Those frameworks are used as anchors that allow the key data to be gathered. Charmaz (2006) called this initial coding. Possible data sources for the grounded theorist are: newspapers and magazines; government reports; political documents, organizational policies; manuals; personal diaries; journals; logbooks; letters; biographies; popular science books; and novels (Birks and Mills 2011). In this case, the author read and codified the content of research articles, cases, and videos $(n=21)$ on the L'Oréal strategy involving The Body Shop, and Natura Cosméticos' strategies involving The Body Shop and Avon Products.

The next step involves adding the frameworks together by demonstrating how each framework can be related to a larger and more inclusive model, as shown in Figure 2. The final step is to integrate frameworks in a theoretical model that holds everything together. Therefore, analytical activities produce a process from which the answer to the research question can be extracted.

As a result, this paper provides examples of the operationalization of the ARCTIC framework. In this respect, the ARCTIC framework contributes to Dyer et al.'s research on the identification of types of synergies. This justifies the current research as being responsive to the different needs of both firms and scholars. However, Dyer et al. (2004) argue that managers should weigh each factor depending on its importance to their industry. Thus, measuring and weighing Dyer's five dimensions could be part of the author's future research work.

After having developed theoretical arguments, the author selected three illustrative case studies-L'Oréal's acquisition and divestiture of The Body Shop (2006 and 2017), and Natura's acquisitions of The Body Shop (2017) and Avon Products (CISION 2019)—-to test the ARCTIC framework's methodology empirically as follows. This is an empirical illustration of the acquisition of relevant outside knowledge, resource, and capabilities (Witt 2016). 


\section{Empirical Testing of the ARCTIC Framework: Findings and Results}

\subsection{L'Oréal's Acquisition of The Body Shop in 2006: What Went Wrong?}

As the world's leading beauty company, L'Oréal is present across all of its industry's distribution networks: the mass market, department stores, pharmacies and drugstores, hair salons, travel retail, branded retail, and e-commerce (L'Oréal Finance 2017). Founded in 1976 by Anita Roddick in Brighton, England, The Body Shop has expanded into a global leader in ethical and natural beauty, with the deep-rooted belief that business can be a force for good (L'Oréal Finance 2017).

When L'Oréal bought the ethical beauty brand The Body Shop back in 2006, it seemed like it could be the brand's big break in the global cosmetic market. At the time, L'Oréal hinted at grand expansion plans, with Brazil, China, and Argentina all tipped as potential markets for The Body Shop's unashamedly green brand (Cuff 2017). In return, The Body Shop would have enjoyed L'Oréal's research and development tools and marketing expertise, continuing as a unique identity and stand-alone business unit.

4.1.1. The First Step Is to Assess the Core Competencies of Collaborative Partners in Terms of Their Compatibilities, Similarities, and Complementarily

The analysis of core competencies using the VRIO framework (Barney 1996) shows that L'Oréal has a sustainable competitive advantage because of impressive tangible (location, the efficiency of the supply chain) and intangible assets ( $R \& D$, brands, customer loyalty, and patent rights), as well as its superior negotiation and M\&A capabilities. Meanwhile, The Body Shop has the following core competencies: a strong brand name across the globe, high-quality ingredients, and good supplier relationships, which leads to a high repurchase rate from loyal customers who share the same values.

4.1.2. The Second Step Is to Apply the ARCTIC Framework to Predict a Reciprocal Synergy in M\&A Deals

According to the ARCTIC framework given in Table 1, there were three reasons for failure in terms of competence-based synergy: a lack of external relatedness of core competences of both companies, inefficient integration plans, and cultural incompatibility. Even though their competencies are idiosyncratic and the rationale behind takeover was to "help" each other in terms of R\&D (internal advantages), they did not provide a new integrated customer value proposition (lack of relatedness). Next, there was the cultural incompatibility of the two sets of core competencies of L'Oréal and The Body Shop, as shown in Table 1. The acquisition of the company was unsuccessful: it almost lost its niche to newly emerging natural beauty products by reducing external perceptions of its trustworthiness and values in the post-acquisition stage.

Table 1. The ARCTIC (A-Advantage, R-Relatedness, C-Complexity of Competence, T-Time of Integration, I-Implementation Plan, C-Cultural Fit) framework for the pre-acquisition analysis of competence-based synergies (L'Oréal's acquisition of The Body Shop).

\begin{tabular}{|c|c|c|c|c|c|c|}
\hline Core competences of L'Oréal (Loreal) and The Body Shop (TBS) & (A) & (R) & (C) & $(\mathrm{T})$ & (I) & (C) \\
\hline Loreal Core competence in R\&D & Yes & No & Yes & Yes & No & No \\
\hline Loreal Core competence in supply chain management & Yes & No & Yes & Yes & No & No \\
\hline Loreal Core competence in brand management & Yes & No & Yes & Yes & No & No \\
\hline Loreal Core competence in customers' loyalty & Yes & No & Yes & Yes & No & No \\
\hline Loreal Core competence in the product range & Yes & No & Yes & Yes & No & No \\
\hline TBS Core competence in brand management & No & No & Yes & Yes & No & No \\
\hline TBS Core competence in running a global store network & No & No & No & Yes & No & No \\
\hline TBS Core competence in maintaining high-quality ingredients & No & No & Yes & Yes & No & No \\
\hline TBS Core competence in supply chain management & No & No & Yes & Yes & No & No \\
\hline
\end{tabular}


Other reasons behind the post-acquisition failure were inefficiencies, short-term integration plans, and unsuccessful capitalization. This can be exemplified by L'Oréal's failure to upgrade The Body Shop's digital presence and product range in line with market trends-contour sticks, kits, palettes, etc.- -and to expand its stores rapidly and globally. The application of the ARCTIC research framework showed a lack of prerequisites of synergies in this acquisition. For that very reason, the author did not apply the five factors of Dyer's framework and real options valuation for further analysis.

\subsection{Natura's Acquisition of The Body Shop in Late 2017: Targeting Global Growth?}

Brazil's Natura Cosméticos S.A. (Natura) was already a stable eco-cosmetic producer in the market when it acquired The Body Shop. Together they had combined net sales of 3.15 billion euros. What is more, the acquisition helped Natura to enter the global market, as it was more focused on Latin America's market. Natura wanted to double earnings at The Body Shop as part of a wider global push to expand its sustainable and ethically oriented brands (Schipani 2018). The combination of these two companies would contribute to the customer value proposition that they have each shared separately, but now as a global cohesive whole.

4.2.1. The First Step Is to Assess the Core Competencies of Collaborative Partners in Terms of Their Compatibilities, Similarities, and Complementarily

The VRIO analysis helped to identify that Natura core competences and therefore strategic competitive advantages (SCAs) come primarily from financial resources, strong leadership in Brazil's market, and a distinctive brand name combined with their partnership with suppliers and hence enabling them to maintain high-quality ingredients. The Body Shop's SCAs include a strong brand name across the globe, high-quality ingredients, and good supplier relations, which leads to a high repurchase rate from loyal customers who share the same values.

4.2.2. The Second Step Is to Apply the ARCTIC Framework to Predict a Reciprocal Synergy in M\&A Deals

Having used the ARCTIC framework as shown in Table 2 and assessed the antecedents of reciprocal synergies, it should be concluded that the combination of core competences of Natura and The Body Shop would help to develop further growth underpinned by competence-based synergies.

Table 2. ARCTIC framework for the pre-acquisition analysis of competence-based synergies (Natura's acquisition of The Body Shop).

\begin{tabular}{lcccccc}
\hline $\begin{array}{l}\text { Core competences of Natura Cosméticos S.A. (Natura) and The } \\
\text { Body Shop (TBS) }\end{array}$ & (A) & (R) & (C) & (T) & (I) & (C) \\
\hline $\begin{array}{l}\text { Natura Core competence in the research of users' needs and } \\
\text { behaviors }\end{array}$ & Yes & Yes & Yes & Yes & Yes & Yes \\
\hline Natura Core competence in high-quality ingredients & Yes & Yes & Yes & Yes & Yes & Yes \\
\hline Natura core competence in brand management & Yes & Yes & Yes & Yes & Yes & Yes \\
\hline Natura core competence in e-commerce & Yes & Yes & Yes & Yes & Yes & Yes \\
\hline $\begin{array}{l}\text { Natura Core competence in delivering natural cosmetics and an } \\
\text { ethical approach to producing cosmetics }\end{array}$ & Yes & Yes & Yes & Yes & Yes & Yes \\
\hline TBS Core competence in brand management & Yes & Yes & Yes & Yes & Yes & Yes \\
\hline TBS Core competence in running a global store network & Yes & Yes & Yes & Yes & Yes & Yes \\
\hline TBS Core competence in maintaining high-quality ingredients & Yes & Yes & Yes & Yes & Yes & Yes \\
\hline TBS Core competence in supply chain management & Yes & Yes & Yes & Yes & Yes & Yes \\
\hline
\end{tabular}


The conclusion on complementarities and compatibilities of their competences and their impact on their global value chain is as follows: Natura's and The Body Shop's core competencies complement each other thanks to their strong loyal customer bases all over the world, worldwide stores, and strong brand management.

\subsubsection{The Third Step Is Defining the Type of Competence-Based Synergy that Both Companies} Would Experience

The author read and codified the content of research articles, cases and videos on Natura Cosméticos' strategy to choose between acquisition and alliances and to predict the type of synergy it could have with The Body Shop (Butler 2017; BBC News 2017; John and Bhagyalakshmi 2017; News News 2017) using the framework developed by Dyer et al. Having used analyses of core competencies of Natura Cosméticos and The Body Shop, the author classified the research results according to the five factors of Dyer's framework. Then, using the frequency of an occurrence, the author determined the recommended type of collaboration strategy and the possible type of competence-based synergy. Having used Dyer et al.'s approach, an acquisition was justified as being the most optimal option for collaboration where both companies would benefit from reciprocal synergies. The reasons for this are as follows: Both companies execute tasks through close knowledge sharing, creating synergy with mostly hard resources, and there are many rivals for potential partners on a global scale. According to the ARCTIC framework, the potential of reciprocal synergies is clear in this case. In this context, Natura sensed that there is global market demand for eco-friendly cosmetic products and seized opportunities through the acquisition of a company with the same principle of being a force for good and a very similar customer value proposition, and transformed their global value chains by globalizing its own operations and promoting a socially responsible business model globally.

\subsubsection{The Fourth Step Is Measuring Competence-Based Synergies in M\&A with a Real Options Valuation}

The first valuation model used for this step was based on the Black Scholes option pricing model (Black and Scholes 1973), namely: $C(S, t)=\mathrm{S}_{0}{ }^{*} N(d 1)-K^{*} e^{-r T *} N(d 2)$, where $N(d 1), N(d 2)$ are the cumulative distribution functions of the standard normal distribution; $C(S, t)$ is call option price at time $t ; S_{0}$ is the price of the underlying asset at time $0 ; K$ is the exercise price at time $t ; T$ is time in years; $r$ is a risk-free rate; $e$ is a mathematical constant approximately equal to 2.71828 , the base of the natural logarithm; $\sigma$ is expected volatility of an underlying asset's value. To value a reciprocal synergy with a real options application, the author used the following data shown in Table 3.

Table 3. Data and methodology to measure competence-based synergies of Natura and The Body Shop's M\&A deal with a real options valuation.

\begin{tabular}{|c|c|c|}
\hline Option Variables & Sources & Data \\
\hline $\begin{array}{l}\text { The price of the underlying asset } \\
\text { at time t } S(t)\end{array}$ & $\begin{array}{l}\text { The number of shares outstanding for } \\
\text { Natura Cosméticos before the } \\
\text { acquisition in } 03.09 .2017 \text { was } \\
\text { 860,743,000 with a price per share of } 15.8 \\
\text { BRL (YahooFinance 2019) or } \$ 5.09 \\
\text { (BRL/US\$ = 0.3222 at 04.09.2017) }\end{array}$ & $\begin{array}{c}\text { Thus, the market capitalization of } \\
\text { Natura Cosméticos was } \$ 4,280,020,834 \\
\text { or } \$ 4.3 \text { bn. The market capitalization } \\
\text { of The Body Shop, as a private } \\
\text { company, was defined as being worth } \\
\$ 1.1 \text { bn, the price that Natura } \\
\text { Cosméticos paid to L'Oréal. } S(t) \text { is } \\
\$ 5.4 \text { bn }\end{array}$ \\
\hline The exercise price $(\mathrm{K})$ & $\begin{array}{c}\text { Natura + Aesop EBITDA, and } \\
\text { EV/EBITDA multiple and The Body } \\
\text { Shop EBITDA, and the EV/EBITDA } \\
\text { (Natura, Aesop, The Body Shop 2017, } \\
\text { pp. 10, 20) }\end{array}$ & $\begin{array}{l}\text { The hypothetical future market value } \\
\text { of Natura equals } \$ 5.01 \mathrm{bn} \text {. The } \\
\text { hypothetical future market value of } \\
\text { The Body Shop equals } \$ 1.1 \mathrm{bn} \text {. Thus, } \\
\text { the strike price }(\mathrm{K}) \text { was } \$ 6.11 \mathrm{bn}\end{array}$ \\
\hline
\end{tabular}


Table 3. Cont.

\begin{tabular}{ccc}
\hline Option Variables & Sources & Data \\
\hline $\begin{array}{c}\text { For the risk-free rate }(\mathrm{Rf}) \text {, the } \\
\text { domestic three-month rate of the } \\
\text { acquirer's country on the } \\
\text { announcement day. }\end{array}$ & $\begin{array}{c}\text { The annualized risk-free interest rate is } \\
\text { Brazilian T-bonds rate taken from } \\
\text { (WorldGovernmentBond 2019) }\end{array}$ & $\begin{array}{c}\text { For Natura \& Co. group, the domestic } \\
\text { three-month rate of the acquirer's } \\
\text { country on the announcement day } \\
\text { was 6.67\% }\end{array}$ \\
\hline Time in years $(t)$ & $\begin{array}{c}\text { Duration }(t) \text { getting synergy of the } \\
\text { merger or acquisition (Natura, Aesop, } \\
\text { The Body Shop 2017, p. 21) }\end{array}$ & $\begin{array}{c}\text { According to Natura and Co group } \\
\text { data, the merger was expected to be } \\
\text { accretive to EBITDA of The Body Shop } \\
\text { in the two years after completion }\end{array}$ \\
\hline $\begin{array}{c}\text { The standard deviation }(\sigma) \text { is the } \\
\text { annualized standard deviation of } \\
\text { weekly returns after the merger. }\end{array}$ & $\begin{array}{c}\text { Natura \& Co., group's historical } \\
\text { volatilities of the merged company } \\
\text { within the first week after the merger } \\
\text { (V-Lab, 2019) }\end{array}$ & $\begin{array}{c}\text { Thus, expected volatility }(\sigma) \text { equals } \\
\sigma=36 \%\end{array}$ \\
\hline
\end{tabular}

Based on the valuation results, the Natura and Co. group would add market value through the acquisition of The Body Shop of around US\$1.11 billion, as shown in Table 4 .

Table 4. Parameters of the Black Scholes option pricing model and the value of reciprocal synergies: European call option value (Natura's acquisition of The Body Shop, in US\$ bn).

\begin{tabular}{|c|c|c|c|}
\hline Option Variables & Data & Option Variables & Data \\
\hline $\mathrm{T}=$ & 2.0000 & $\mathrm{~d}_{1}=$ & 0.2736 \\
\hline $\mathrm{S}_{0} / \mathrm{T}=$ & 0.8838 & $\mathrm{~N}\left(\mathrm{~d}_{1}\right)=$ & 0.6078 \\
\hline $\ln \left(\mathrm{S}_{0} / \mathrm{K}\right)=$ & -0.1235 & $\mathrm{~d}_{2}=$ & -0.2356 \\
\hline variance $/ 2=$ & 0.0648 & $\mathrm{~N}\left(\mathrm{~d}_{2}\right)=$ & 0.4069 \\
\hline [risk-free rate + variance $/ 2]{ }^{*} \mathrm{~T}=$ & 0.2628 & $-\mathrm{rT}=$ & -0.1332 \\
\hline square root of variance $=$ & 0.3600 & $\mathrm{e}^{-\mathrm{rT}}=$ & 0.8753 \\
\hline square root of $\mathrm{T}=$ & 1.4142 & $\mathrm{~S}_{0} * \mathrm{~N}\left(\mathrm{~d}_{1}\right)=$ & US \$3.28 \\
\hline \multirow[t]{2}{*}{$\begin{array}{l}\text { (square root of variance) } \\
*(\text { square root of } \mathrm{T})=\end{array}$} & 0.5091 & 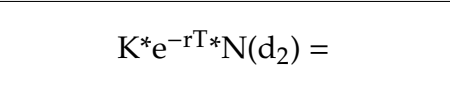 & US $\$ 2.18$ \\
\hline & & $\begin{array}{l}\text { Real option value: the value of } \\
\text { reciprocal synergies, } C=\end{array}$ & US $\$ 1.11 \mathrm{bn}$ \\
\hline
\end{tabular}

According to BS-OPM, by acquiring The Body Shop, Natura and Co. group would have obtained an increased market value of about $\$ 1.11$ billion.

Afterwards, the author applied the BOPM. This method can be applied based on the assumption that the value of an underlying asset follows the binominal process over discrete periods (Cox et al. 1979). This process can be presented in the form of a binomial lattice. The lattice of the underlying value of the Natura \& Co. group after The Body Shop acquisition is given in Table 5 .

According to Mun (2002, p. 143), the risk-neutral probability (p) allows us to value real options in the risk-neutral world and thus to discount the value of the underlying assets using a risk-free rate. Therefore, risk-neutral probability does not represent any objective probability; instead, it is just a mathematical intermediate (Kodukula and Papudesu 2006, p. 74). The calculation of the up factor $(u)$, down factors $(d)$, and the risk-neutral probability (p) was made as shown in Table 6. 
Table 5. The binominal option pricing model: a lattice of the underline values of Natura's acquisition of The Body Shop (in US\$ bn).

\begin{tabular}{|c|c|c|c|c|c|}
\hline Stepping Time: $\delta t 0$ & $\delta t 1$ & $\delta t 2$ & $\delta t 3$ & $\delta t 4$ & $\delta t 5$ \\
\hline \multirow{11}{*}{$\begin{array}{l}\text { Underline value: } \\
\qquad \$ 5.40\end{array}$} & & & & & $\$ 16.86$ \\
\hline & & & & $\$ 13.43$ & \\
\hline & & & $\$ 10.69$ & & $\$ 10.69$ \\
\hline & & $\$ 8.51$ & & $\$ 8.51$ & \\
\hline & $\$ 6.78$ & & $\$ 6.78$ & & $\$ 6.78$ \\
\hline & & $\$ 5.40$ & & $\$ 5.40$ & \\
\hline & $\$ 4.30$ & & $\$ 4.30$ & & $\$ 4.30$ \\
\hline & & $\$ 3.42$ & & $\$ 3.42$ & \\
\hline & & & $\$ 2.73$ & & $\$ 2.73$ \\
\hline & & & & $\$ 2.17$ & \\
\hline & & & & & $\$ 1.73$ \\
\hline
\end{tabular}

The binomial lattice parameters that were obtained after the recombining process are given in Table 6 below.

Table 6. Recombining binomial lattice parameters (Natura's acquisition of The Body Shop).

\begin{tabular}{cc}
\hline Parameters That Affect the American Real Option's Value \\
\hline Stepping time: $\delta t$ (year) & 0.40 \\
Up factor: $(u)$ & 1.256 \\
Down factor: $(d)$ & 0.796 \\
Neutral risk probability: $(p)$ & 0.502 \\
\hline
\end{tabular}

The real options valuation lattice for Nature \& Co group after the acquisition of the Body Shop is given in Table 7.

Table 7. Binominal Option pricing model. Real options lattice: a value of synergies of Natura's acquisition of The Body Shop (in US\$ bn).

\begin{tabular}{|c|c|c|c|c|c|}
\hline Stepping Time: $\delta t 0$ & $\delta t 1$ & $\delta t 2$ & $\delta t 3$ & $\delta t 4$ & $\delta t 5$ \\
\hline \multirow{10}{*}{ Real option's value (value of synergies): } & \multirow{6}{*}{$\$ 1.88$} & \multirow[b]{4}{*}{$\$ 3.08$} & & & $\$ 10.75$ \\
\hline & & & & $\$ 7.48$ & \\
\hline & & & $\$ 4.90$ & & \multirow{2}{*}{$\$ 4.58$} \\
\hline & & & & $\$ 2.57$ & \\
\hline & & \multirow[b]{2}{*}{$\$ 0.77$} & $\$ 1.41$ & & \multirow[t]{2}{*}{$\$ 0.67$} \\
\hline & & & & $\$ 0.33$ & \\
\hline & $\$ 0.41$ & \multirow{3}{*}{$\$ 0.08$} & $\$ 0.16$ & & \multirow[t]{2}{*}{$\$ 0.00$} \\
\hline & & & & $\$ 0.00$ & \\
\hline & & & $\psi 0.00$ & $\$ 0.00$ & $\$ 0.00$ \\
\hline & & & & & $\$ 0.00$ \\
\hline
\end{tabular}

According to BS-OPM and BOPM, the Natura and Co. group would have added an increased market value of about \$1.11-1.12 billion. Therefore, the expected market value (eNPV) of merging the Natura and Co. group is the cumulated future market value of target and acquirer after the announcement (E) of $\$ 6.11$ bn plus competence-based synergies of $\$ 1.11$ bn equals the future market value of $\$ 7.22 \mathrm{bn}$. As of the date of this research (10 October 2019), the market capitalization of Natura and Co group is $\$ 671$ bn (Bloomberg 2017), which is $\$ 0.5$ bn less than the paper predicted. The estimated value of synergies shows evidence that Natura and Co have not fully realized their forecasted reciprocal synergies (real options value) thus far. 


\subsection{Natura's Acquisition of Avon Products Inc. in 2019: Creating a Global Cosmetic Powerhouse?}

In 22 May 2019, Brazil's Natura confirmed a US\$2 bn deal to buy Avon Products Inc. By buying Avon, Natura will be able to expand its global value chain, particularly in Asia, Europe, and Latin America. Avon, which is based in London and listed in New York, has struggled in recent years, and in January 2019, the company cut 2300 jobs (Fontanella-Khan and Schipani 2019). For 130 years, Avon has stood for women by providing innovative and high-quality beauty products that are primarily sold to women by women. The company pioneered the direct-selling model in cosmetics-which is embodied by its doorstep Avon Lady sellers. But it has lost market share to savvier competitors such as LVMH-owned Sephora, Estée Lauder, and L'Oréal as the rise of social media disrupted the cosmetics business. Natura, which has been eyeing opportunities to expand globally, believes it can revive Avon's fortunes.

4.3.1. The First Step Is to Assess the Core Competencies of Collaborative Partners in Terms of Their Compatibilities, Similarities, and Complementarily

The VRIO analysis helped to identify that Avon core competences and therefore strategic competitive advantages (SCAs) come primarily from having an iconic brand, strong direct marketing programs, personalized direct selling experiences, a vast products mix, and a global presence. Natura's recent purchase of Body Shop and now its acquisition of Avon bolsters the brand on the global level, enabling it to leverage Avon's direct sales model with Body Shop's brick-and-mortar stores to give shoppers more ways to engage with and purchase from the brand.

\subsubsection{The Second Step Is to Apply the ARCTIC Framework to Predict a Reciprocal Synergy in M\&A Deals}

Having used the ARCTIC framework as shown in Table 8 and assessed the acquisition of Avon Production Inc. regarding antecedents of reciprocal synergies, it should be concluded that working together they would generate competence-based synergies by fostering digital capabilities, leveraging their global value chain, and milking their distinctive brands. Thus, this strategic step by Natura Group creates a global cosmetic powerhouse.

Table 8. ARCTIC framework for the pre-acquisition analysis of competence-based synergies (Natura's acquisition of Avon Products Inc.).

\begin{tabular}{lcccccc}
\hline $\begin{array}{l}\text { Core competences of Natura Cosméticos S.A. (Natura), The Body } \\
\text { Shop (TBS), and Avon Products Inc. (Avon) }\end{array}$ & (A) & (R) & (C) & (T) & (I) & (C) \\
\hline $\begin{array}{l}\text { Natura's Core competence in the research of users' needs and } \\
\text { behaviors }\end{array}$ & Yes & Yes & Yes & Yes & Yes & Yes \\
\hline Natura's Core competence in high-quality ingredients & Yes & Yes & Yes & Yes & Yes & Yes \\
\hline Natura's Core competence in brand management & Yes & Yes & Yes & Yes & Yes & Yes \\
\hline Natura's Core competence in e-commerce & Yes & Yes & Yes & Yes & Yes & Yes \\
\hline $\begin{array}{l}\text { Natura's Core competence in delivering natural cosmetics and an } \\
\text { ethical approach to producing cosmetics }\end{array}$ & Yes & Yes & Yes & Yes & Yes & Yes \\
\hline Avon's Core competence in maintaining a global presence & Yes & Yes & Yes & Yes & Yes & Yes \\
\hline Avon's Core competence in maintaining an iconic brand & Yes & Yes & Yes & Yes & Yes & Yes \\
\hline $\begin{array}{l}\text { Avon's Core competence in running strong direct marketing } \\
\text { programs }\end{array}$ & No & No & Yes & Yes & No & No \\
\hline $\begin{array}{l}\text { Avon's Core competence in developing personalized direct selling } \\
\text { experiences }\end{array}$ & No & No & Yes & Yes & No & No \\
\hline Avon's Core competence in having a vast products mix & Yes & Yes & Yes & Yes & Yes & Yes \\
\hline
\end{tabular}

Avon can take advantage of Natura's natural and ethical products and benefit from Natura's expertise and association to strengthen its position in the market. However, according to the ARCTIC framework, there are possible challenges that Natura could face following the acquisition of Avon 
(A; R). Natura acquired the Body Shop and Aesop with the hopes to align their organizational cultures (C) and their value to its own. But Avon's culture and values are different. It would be challenging for Natura to see how Avon's culture and value affected its approach. Though Avon's traditional direct selling model in Latin America has not faced much of a problem in the Brazilian market due to growing e-commerce, the same cannot be said to be true ( $R$; I) for Avon's other regions (Sahu and Pereru 2019, p. 4).

\subsubsection{The Third Step Is Defining the Type of Competence-Based Synergy that Both Companies} Would Experience

Beauty is one of the fastest-growing retail product categories, and further consolidation in the industry space may be expected. Already established in South America and Latin America, Natura is strengthening its operations in the U.S. to better compete with L'Oréal SA and Estee Lauder Cos., the world's two largest beauty businesses. The acquisition of Natura will enable them to better serve their millions of representatives, leveraging Avon's global presence, and getting a reciprocal strategic synergy. According to the analysis of the type of competence-based synergies, all five factors of Dyer at al. framework (2004) suggest that a reciprocal form of synergies and acquisition is the most optimal strategic option for potential partners, and the synergy would be created mostly by using hard resources. However, according to the ARCTIC framework, collaboration's reciprocal synergies can be a bit problematic to develop.

4.3.4. The Fourth Step Is Valuing the Reciprocal Synergy of M\&A Deal with a Real Option Application

To value reciprocal synergy, this paper used the Data shown in Table 9.

Table 9. Data and methodology to measure competence-based synergies of the Natura \& Avon M\&A deal with a real options valuation.

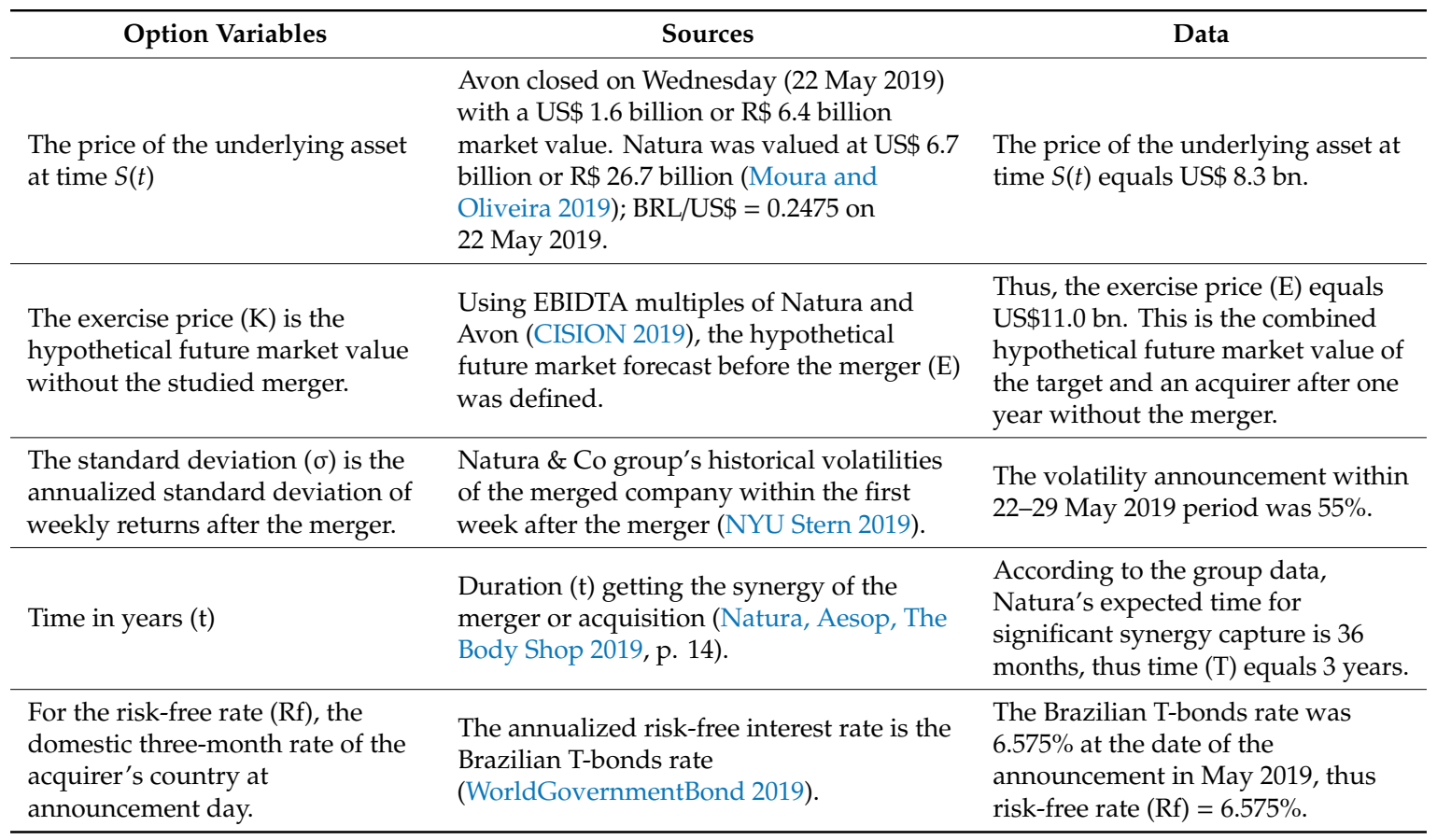

Based on these valuation results, the Natura and Co. group would add market value through the acquisition of Avon Products Inc. of about US\$ 2.8 billion, as shown in Tables 10-13. 
Table 10. Parameters of Black Scholes option pricing model and the value of reciprocal synergies: the European call option value (Natura's acquisition of Avon Products Inc, in US\$ bn).

\begin{tabular}{|c|c|c|c|}
\hline Option Variables & Data & Option Variables & Data \\
\hline $\mathrm{T}=$ & 3.0000 & $\mathrm{~d}_{1}=$ & 0.3879 \\
\hline $\mathrm{S}_{0} / \mathrm{T}=$ & 0.7545 & $\mathrm{~N}\left(\mathrm{~d}_{1}\right)=$ & 0.6509 \\
\hline $\ln \left(\mathrm{S}_{0} / \mathrm{K}\right)=$ & -0.2816 & $\mathrm{~d}_{2}=$ & -0.5647 \\
\hline variance $/ 2=$ & 0.1513 & $\mathrm{~N}\left(\mathrm{~d}_{2}\right)=$ & 0.2861 \\
\hline [risk-free rate + variance $/ 2]^{*} \mathrm{~T}=$ & 0.6512 & $-\mathrm{rT}=$ & -0.1974 \\
\hline square root of variance $=$ & 0.5500 & $\mathrm{e}^{-\mathrm{rT}}=$ & 0.8209 \\
\hline square root of $\mathrm{T}=$ & 1.7321 & $\mathrm{~S}_{0} * \mathrm{~N}\left(\mathrm{~d}_{1}\right)=$ & US $\$ 5.40$ \\
\hline \multirow[t]{2}{*}{$\begin{array}{l}\text { (square root of variance)*(square } \\
\operatorname{root} \text { of } \mathrm{T})=\end{array}$} & 0.9526 & $\mathrm{~K}^{*} \mathrm{e}^{-\mathrm{rT} *} \mathrm{~N}\left(\mathrm{~d}_{2}\right)=$ & US $\$ 2.58$ \\
\hline & & $\begin{array}{l}\text { Real option value: the value of } \\
\text { reciprocal synergies, } C=\end{array}$ & US\$ 2.82 \\
\hline
\end{tabular}

Table 11. Binominal option pricing model. The lattice of the underline values of Natura's acquisition of Avon Products Inc. (in US\$ bn).

\begin{tabular}{|c|c|c|c|c|c|}
\hline Stepping Time: $\delta t 0$ & $\delta t 1$ & $\delta t 2$ & $\delta t 3$ & $\delta t 4$ & $\delta t 5$ \\
\hline $\begin{array}{l}\text { Underline value: } \\
\qquad \$ 8.30\end{array}$ & $\begin{array}{l}\$ 12.71 \\
\$ 5.42\end{array}$ & $\begin{array}{l}\$ 19.46 \\
\$ 8.30 \\
\$ 3.54\end{array}$ & $\begin{array}{l}\$ 29.79 \\
\$ 12.71 \\
\$ 5.42 \\
\$ 2.31\end{array}$ & $\begin{array}{l}\$ 45.62 \\
\$ 19.46 \\
\$ 8.30 \\
\$ 3.54 \\
\$ 1.51\end{array}$ & $\begin{array}{l}\$ 69.85 \\
\$ 29.79 \\
\$ 12.71 \\
\$ 5.42 \\
\$ 2.31 \\
\$ 0.99\end{array}$ \\
\hline
\end{tabular}

Table 12. Recombining binomial lattice parameters (Natura's acquisition of Avon Products Inc).

\begin{tabular}{cc}
\hline Parameters That Affect the American Real Option's Value \\
\hline Stepping time: $\delta t$ (year) & 0.60 \\
Up factor: $(u)$ & 1.531 \\
Down factor: $(d)$ & 0.653 \\
Neutral risk probability: $(p)$ & 0.441 \\
\hline
\end{tabular}

Table 13. Binominal Option pricing model. Real options lattice: a value of synergies of Natura's acquisition of Avon Products Inc. (in US\$ bn).

\begin{tabular}{|c|c|c|c|c|c|}
\hline Stepping Time: $\delta t 0$ & $\delta t 1$ & $\delta t 2$ & $\delta t 3$ & $\delta t 4$ & $\delta t 5$ \\
\hline $\begin{array}{l}\text { Real option's value (synergies): } \\
\qquad 2.81\end{array}$ & $\begin{array}{l}\$ 5.51 \\
\$ 0.89\end{array}$ & $\begin{array}{l}\$ 10.55 \\
\$ 1.93 \\
\$ 0.13\end{array}$ & $\begin{array}{l}\$ 19.63 \\
\$ 4.15 \\
\$ 0.31 \\
\$ 0.00\end{array}$ & $\begin{array}{c}35.05 \$ \\
\$ 8.88 \\
\$ 0.72 \\
\$ 0.00 \\
\$ 0.00\end{array}$ & $\begin{array}{l}\$ 58.85 \\
\$ 18.79 \\
\$ 1.71 \\
\$ 0.00 \\
\$ 0.00 \\
\$ 0.00\end{array}$ \\
\hline
\end{tabular}


The expected added market value (eNPV) of the Natura and Co. group after Avon Products' acquisition is the cumulated future market value of the target and the acquirer after the announcement (K) of US $\$ 11.0$ bn plus the competence-based synergies value of US $\$ 2.8$ bn equals the future market value at US $\$ 13.8$ bn that would be realized until June of 2022, as expected by Natura Holding S.A. (Natura, Aesop, The Body Shop 2019, p. 14). Therefore, the measurement of reciprocal synergies by the real options contributes and advances strategy research on real options and brings the real options theory and the valuation/analytical perspective closer together (Trigeorgis and Reuer 2017).

\section{Discussion}

What lessons learned can be distilled from the conducted case studies that should be considered in future research? Firstly, cultural differences between merging companies can become insurmountable obstacles towards creating a competence-based synergy. Secondly, knowledge creation and dissemination among partners are keys to the promotion of either sequential or reciprocal synergies. This is true for global cosmetic powerhouses such as Natura Group and for social networks, as shown in previous research (Čirjevskis 2015, Čirjevskis 2019).

L'Oréal demonstrated insufficient capabilities to upgrade The Body Shop's digital presence and its product range, as well as to expand its stores rapidly and globally. In contrast, Natura was targeting the booming global natural and organic beauty market and saw The Body Shop and Avon as opportunities that could give its global expansion a boost. The acquisition of The Body Shop and Avon by Natura transformed the combined entity into one of the world's largest beauty conglomerates. With those acquisitions, Natura gained great geographic diversification, and thus maximized its shareholders' wealth.

The current paper makes several theoretical and empirical contributions to three different knowledge areas: real options theory (ROT), international business (IB), and strategic management. Regarding the contribution to a ROT, Trigeorgis and Reuer (2017, p. 59) encourage new methodologies with a greater focus on the individual project level of analysis from a strategic perspective, and the collection of more data on individual real option cases. This paper contributes to this request in several ways. First, a ROT acknowledges the importance of resources, knowledge, and capabilities, but it focuses attention on new sources of competitive advantage: to acquire and to exercise appropriate growth options in the right geographic location (Chi et al. 2019; Chang and Rosenzweig 2001). This paper justifies this proposition by adding fresh empirical evidence on how Brazilian Natura \& Co is creating a cosmetic powerhouse by exercising growth options on a global scale. Second, firms should make thorough selections of their acquisition's targets and not pay too high a premium to obtain them. In the case of a successful acquisition, the premium paid should not and cannot be greater than the benefits of a potential synergy (Hitt et al. 2009). The research justifies this proposition as well.

When it comes to the contribution to IB, an application of the ARCTIC framework goes beyond the application of VRIO resources to operations of an individual corporation in individual foreign countries (Ghemawat 2007; Kogut 1985). Moreover, recent research (Chi et al. 2019) points out the ability to switch as another source of competitive advantage built into multinational corporation acquired affiliates. This paper empirically justifies this proposition and illustrates how over the last decade, Natura Group has profoundly changed its strategies to leverage the opportunities of globalization and to organize activities across their geographical boundaries. Thus, the research contributes to examining Natura's global strategies, its leveraging of cross-border connectivity, and the management of its global value chain. Having contributed and advanced empirical research in IB, ROT, and the core competence theory of strategic management, the author has developed practical recommendations on international M\&A deals, as shown in Figure 3.

Figure 3 provides a holistic view of the ARCTIC model and real options valuation and synthesizes the key ideas in the current paper. In practice, the managerial application of the proposed framework consists of four steps. It maps out a new framework that incorporates both the core competence theory and real option theory concepts affecting a MNE's abilities to create a reciprocal synergy through 
M\&A processes and realize their value of synergies to enhance sustained competitive advantages. Thus, Figure 2 explains the relationship between the antecedents of competence-based synergies in M\&A deals and summarizes the theoretical and empirical contributions of the paper.

-An assessment of strategic similarities, compatibilities, and complementarities of core
competences of collaborative partners

Figure 3. The relationships among developed steps for a preliminary assessment of the success of M\&A deals.

\section{Conclusions, Research Limitations, and Future Work}

Regarding theoretical contribution to strategic management, the six success factors of the ARCTIC framework allow a preliminary assessment of the success of M\&A deals as shown in the research, and this is the main theoretical contribution of this paper. Moreover, the current paper contributes and advances the strategic management discipline by answering the question of the Strategy Practice group of the Strategic Management Society: "How can we better leverage on a multi-disciplinary approach to inform and advance the strategy practice agenda?" (Strategic Management Society and Strategy Practice IG 2020). The answer to the research question is given empirically in Tables 1-13 as follows. The valuation of competence-based synergies by using real options gives practitioners a clearer strategic observation of the reciprocal synergism of a M\&A deal. The application of the real options helps to estimate a synergy in terms of market value-added, not only in terms of cost-saving and/or revenues rising.

Regarding limitations, the author integrated success factors into six larger groups, for example, combining the manageability and absorption capacity of technology into complexity. The decomposition of each factor of the ARCTIC framework into sub-factors (at least three in one group) would help in performing new quantitative research using the ARCTIC framework. This, of course, is a prospective arena for future research. What is more, the ARCTIC framework might be useful for predicting the synergy of cooperative arrangements, many forms of alliances, and networking organizations.

This study also raises several empirical issues that may be addressed in future research. One more channel for the future research direction is corporate governance issues which determine how synergies in M\&A are identified or created. Recent research has explored the effects of governance on long-horizon stock returns, firm value, and operating performance (Giroud and Mueller 2011). Therefore, the effects of governance on competence-based synergies in M\&A deals are an intriguing unit of research. More empirical research is needed to assess the impact of compensation gap (Coles et al. 2018; Li 2014) 
between a CEO at a target company and the CEO acquirer's company on the time of integration process (T) of core competences and the organization (I) of core competence transfer in the M\&A process.

Executive compensation theory ( $\mathrm{Li}$ et al. 2018), the impact on reciprocal synergies of agency problems, mutual monitoring and corporate governance systems (Li 2014), and an external interaction between CEOs in M\&A deals are promising areas of future research as well. In these contexts, the real options theory helps us to better understand the antecedents of reciprocal synergies in the international M\&A deals and to achieve the realization of synergies valuing by using a real option application.

Funding: This research received no external funding.

Acknowledgments: This article is based on conference manuscripts presented at Academy of International Business (AIB) 2019 Annual Meeting, Copenhagen, Denmark, and Academy of Management (AOM) Specialized Conference Advancing Management Research in Latin America 2020, in Mexico City (this conference has been cancelled cancelled due to the coronavirus pandemic). The previous manuscripts have been extended with new empirical and secondary data based on current research. The author would like to thank the reviewers of the AIB and AOM conferences' manuscripts (Čirjevskis 2019, Čirjevskis 2020)and two anonymous reviewers from the Administrative Science journal for their valuable comments, recommendations, and insights.

Conflicts of Interest: The authors declare no conflict of interest.

\section{References}

Alhenawi, Yasser, and Sudha Krishnaswami. 2015. The long-term impact of merger synergies on performance and value. The Quarterly Review of Economics and Finance 58: 93-118. [CrossRef]

Alhenawi, Yasser, and Martha L. Stilwell. 2018. Toward a complete definition of relatedness in merger and acquisition transactions. Review of Quantitative Finance and Accounting 53: 1-46. [CrossRef]

Andrade, Gregor, Mark Mitchell, and Erik Staffors. 2001. New evidence and perspective on the merger. Journal of Economic Perspectives 15: 103-20. [CrossRef]

Arzuaga, Susel, Ann Palomino Brown, and Martin Rich. 2014. Generating Theory from Secondary Data: A Variation on Eisenhardt's Case Study Method. Paper presented at the 13th European Conference on Research Methodology for Business and Management Cass Business School City University, London, UK, June 16-17; Edited by A. Brown and M. Rich. South Oxfordshire: Academic Conferences and Publishing International Ltd.

Barney, Jay B. 1996. Gaining and Sustaining Competitive Advantage. Boston: Addison-Wesley.

Bauer, Florian, and Kurt Matzler. 2014. Antecedents on M\&A success: The role of strategic complementary, cultural fit, and degree and speed on integration. Strategic Management Journal 35: 269-91.

BBC News. 2017. Body Shop Bought by Brazil's Natura. June 27. Available online: https://www.bbc.com/news/ business-40417961 (accessed on 17 October 2019).

Bijlsma-Frankema, Katinka. 2001. On managing cultural integration and cultural change processes in mergers and acquisitions. Journal of European Industrial Training 25: 192-207. [CrossRef]

Birks, Melanie, and Jane Mills. 2011. Grounded Theory: A Practical Guide. London: Sage.

Black, Thomas R. 1993. Evaluating Social Science Research. London: Sage.

Black, Fischer, and Myron Scholes. 1973. The Pricing of Options and Corporate Liabilities. Journal of Political Economy 81: 637-54. [CrossRef]

Bloomberg. 2017. Brazil's Natura Set to Buy Body Shop in \$1.1 Billion Deal. Available online: https://www.bloomberg. com/news/articles/2017-06-09/brazil-s-natura-set-to-acquire-body-shop-in-1-1-billion-deal (accessed on 17 October 2019).

Bowman, Edward H. 1978. Strategy, annual reports, and alchemy. California Management Review 20: 64-71. [CrossRef]

Butler, Sarah. 2017. L'Oréal to sell Body Shop to Brazil's Natura in €1bn deal. The Guardian, June 9. Available online: https://www.theguardian.com/business/2017/jun/09/loreal-body-shop-natura-aesop (accessed on 17 October 2019).

Cartwright, Susan, and Richard Schoenberg. 2006. Thirty years of mergers and acquisitions research: Recent advances and future opportunities. British Journal of Management 17: S1-S5.

Chang, Sea-Jin, and Philip M. Rosenzweig. 2001. The choice of entry mode in sequential foreign direct investment. Strategic Management Journal 22: 747-76. [CrossRef] 
Charmaz, Kathy. 2006. Constructing Grounded Theory. A Practical Guide through Qualitative Analysis. London: Sage. Chi, Tailan. 2000. Option to acquire or divest a joint venture. Strategic Management Journal 21: 665-87. [CrossRef]

Chi, Tailan, and Anju Seth. 2009. A dynamic model of the choice of mode for exploiting complementary capabilities. Journal of International Business Studies 40: 365-87. [CrossRef]

Chi, Tailan, Jing Li, Lenos G. Trigeorgis, and Andrianos E. Tsekrekos. 2019. Real option theory in international business. Journal of International Business Studies 50: 525-53. [CrossRef]

Chirjevskis, Andrejs, and Lev Joffe. 2007. How to Create Competence-based Synergy in M\&A? The Icfai Journal of Mergers \& Acquisitions IV: 43-61.

Čirjevskis, Andrejs. 2015. Empirical testing of the ARCTIC model for assessment of competence-based synergy in the acquisition process. Journal of Business Management 9: 63-73.

Čirjevskis, Andrejs. 2019. Managing Competence-Based Synergy in Acquisitions Processes: Empirical Evidence from Global ICT and Cosmetic Industries. Interactive Session 3.1.16, Track: 6-Strategy, Organization, and Management. Copenhagen: Academy of International Business (AIB), Available online: https://documents.aib.msu.edu/ events/2019/AIB2019_Program.pdf (accessed on 28 April 2020).

Čirjevskis, Andrejs. 2020. Brazilian Natura \& Co: Creating Cosmetic Powerhouse. Empirical Evidence of Competence-Based Synergies in M\&A processes. Paper presented at "From Innovation to Sustainable Business Models" Specialized Conference of Academy of Management (USA) "Advancing Management Research in Latin America", Mexico City, Mexico. Available online: https://na.eventscloud.com/ehome/index. php? eventid=450962\&tabid=1014207 (accessed on 14 April 2020).

CISION. 2020. PR Newswire. 2020. Natura \& Co to Close Acquisition of Avon, Creating the World's Fourth-Largest Pure-Play Beauty Group. Available online: https://www.prnewswire.com/news-releases/natura-co-to-closeacquisition-of-avon-creating-the-worlds-fourth-largest-pure-play-beauty-group-300980823.html (accessed on 12 April 2020).

CISION PR Newswire. 2019. Natura \& Co and Avon join forces to create a Direct-to-Consumer Global Beauty Leader. Vila Jaguara: Natura \& Co., Available online: https://www.prnewswire.com/news-releases/natura-coand-avon-join-forces-to-create-a-direct-to-consumer-global-beauty-leader-300855548.html (accessed on 1 November 2019).

Coff, Russel W. 2002. Human capital, shared expertise, and the likelihood of impasse in corporate acquisitions. Journal of Management 28: 107-28. [CrossRef]

Coles, Jeffrey L., Zhichuan (Frank) Li, and Albert Y. Wang. 2018. Industry Tournament Incentives. Review of Financial Studies 31: 1418-59. [CrossRef]

Collis, Jill, and Roger Hussy. 2009. Business Research, 3rd ed. London: Palgrave Macmillan, pp. 164-66.

O'Connor, Cliodhna, and Helene Joffe. 2020. Intercoder Reliability in Qualitative Research: Debates and Practical Guidelines. International Journal of Qualitative Methods Volume 19: 1-13. [CrossRef]

Cox, John, Stephen A. Ross, and Mark Rubinstein. 1979. Option Pricing: A Simplified Approach. Journal of Financial Economics 7: 229-63. [CrossRef]

Coyne, Kevin P., Stephen J. D. Hall, and Patricia Gorman Clifford. 1997. Is Your Core Competence a Mirage? McKinsey Quarterly 1: 40-55.

Cuff, Madeleine. 2017. Revealed: The Inside Story of Natura's Body Shop Buyout. BusinessGreen. Available online: https://www.businessgreen.com/bg/interview/3022787/revealed-the-inside-story-of-naturas-bodyshop-buyout (accessed on 17 October 2019).

Dagnino, Giovanni Battista, and Maria Cristina Cinici. 2016. Research Method for Strategic Management. Routledge. London and New York: Taylor \& Francis Group, p. 363.

De Carolis, Donna Marie. 2003. Competences and imitability in the pharmaceutical industry: An analysis of their relationship with firm performance. Journal of Management 29: 27-50. [CrossRef]

Dunis, Christian L., and Til Klein. 2005. Analyzing Mergers and Acquisitions in European Financial Services: An Application of Real Options. European Journal of Finance 11: 339-55. [CrossRef]

Dyer, Jeffrey H., Prashant Kale, and Harbir Singh. 2004. When to Ally and When to Acquire. Harvard Business Review 82: 108-15.

Eisenhardt, Kathleen M., and Melissa E. Graebner. 2007. Theory building from cases: Opportunities and challenges. Academy of Management Journal 50: 25-32. [CrossRef] 
Fontanella-Khan, James, and A. Schipani. 2019. Body Shop Parent Agrees to Buy Avon in an All-Stock Deal. Financial Times. Available online: https://www.ft.com/content/fbed818c-7c4b-11e9--81d2-f785092ab560 (accessed on 1 November 2019).

Ghemawat, Pankaj. 2007. Managing differences: The central challenge of global strategy. Harvard Business Review 85: 58-68.

Giroud, Xavier, and Holger M. Mueller. 2011. Corporate governance, product market competition, and equity prices. Journal of Finance 66: 563-600. [CrossRef]

Grant, Robert M. 1996. Toward a Knowledge-Based Theory of the Firm. Strategic Management Journal 17: 109-22. [CrossRef]

HBS Working Knowledge. 2017. Amazon-Whole Foods Deals Is a Big Win for Consumers. Available online: https://www.forbes.com/sites/hbsworkingknowledge/2017/06/17/amazon-whole-foods-deal-is-abig-win-for-consumers/\#706c71347232 (accessed on 17 January 2018).

Hitt, Michael A., David King, Hema Krishnan, Marianna Makri, Mario Schijven, Katsuhiko Shimizu, and Hong Zhu. 2009. Merger and Acquisition: Overcoming pitfalls, building synergy, and creating value. Business Horizon 52: 523-29. [CrossRef]

John, Doris Rajakumari, and K. Bhagyalakshmi. 2017. L'Oréal's Body Shop Acquisition. What Went Wrong? [Case]. Bangalore: Amit Research Centers Headquarters. Available online: https://www.thecasecentre.org (accessed on 17 October 2019).

Kodukula, Prasad, and Chandra Papudesu. 2006. Project Valuation Using Real Options: A Practitioner's Guide. Fort Lauderdale: Ross Publishing, Inc., pp. 40-135.

Kogut, Bruce. 1985. Designing global strategies: Comparative and competitive value-added chains. Sloan Management Review 26: 15-28.

L'Oréal Finance. 2017. L'Oréal and Natura Enter into Exclusive Discussions Regarding The Body Shop. L'Oréal Finance. Available online: https://www.loreal-finance.com/eng/news/loreal-and-natura-enter-into-exclusivediscussions-regarding-the-body-shop-1193.htm (accessed on 17 October 2019).

Lawrence, C. 2018. DZone. Will Walmart's Bet on IBM Blockchain Pay Off. Available online: https://dzone.com/ articles/will-walmarts-bet-on-ibm-blockchain-pay-off29 (accessed on 29 April 2019).

Li, Zhichuan (Frank). 2014. Mutual monitoring and corporate governance. Journal of Banking E Finance 45: 255-69.

Li, Jing, Charles Dhanaraj, and Richard L. Shockey Jr. 2008. Joint venture evolution: Extending the real options approach. Managerial and Decision Economics 29: 317-36. [CrossRef]

Li, Zhichuan (Frank), Shannon Lin, Shuna Sun, and Alan Tucker. 2018. Risk-Adjusted Inside Debt. Global Finance Journal 35: 12-42. [CrossRef]

Lodorfos, George, and Agyenin Boateng. 2006. The role of culture in the merger and acquisition process: Evidence from the European chemical industry. Management Decision 44: 1405-21. [CrossRef]

Loukianova, Anna, Egor Nikulin, and Andrey Vedernikov. 2017. Valuing synergies in strategic mergers and acquisitions using the real options approach. Investment Management and Financial Innovations 14: 236-47. [CrossRef]

Merchant, Hermant. 2004. Revisiting shareholder value creation via international joint ventures: Examining interactions among firm- and context-specific variables. Canadian Journal of Administrative Sciences 21: 129-45. [CrossRef]

Moura, Júlia, and Filipe Oliveira. 2019. Natura Buys Avon and Becomes the 4th Largest Beauty Company in The World. Folha de S. Paulo. Available online: https://www1.folha.uol.com.br/internacional/en/business/ 2019/05/natura-buys-avon-and-becomes-the-4th-largest-beauty-company-in-the-world.shtml (accessed on 1 November 2019).

Mun, Johnathan. 2002. Real Options Analysis, Tools, and Techniques for Valuing Strategic Investments and Decisions. Hoboken: John Wiley and Sons, pp. 11-262.

Natura, Aesop, The Body Shop. 2017. A Purpose-Driven, Global, Multichannel Cosmetics Group. Available online: https://natu.infoinvest.com.br/enu/6815/Equity\%20story_v26_London_11Sep.pdf (accessed on 17 October 2019).

Natura, Aesop, The Body Shop. 2019. Natura \&Co and Avon: Creating a Leading Direct-to-Customer Global Beauty Group. Available online: https:/www.avonworldwide.com/dam/jcr:e423d61e-19d1-4bdd-b27399229f3e7970/natura-co-avon-webcast.pdf (accessed on 1 November 2019). 
Netz, Joakim, Martin Svensson, and Ethel Brundin. 2019. Business disruptions and affective reactions: A strategy-as-practice perspective. Long Range Planning. Long Range Planning. Available online: https://doi.org/10.1016/j.lrp.2019.101910 (accessed on 28 April 2020).

News News. 2017. The Body Shop, the Brazilians, Bought It [Video clip]. Available online: https://www.youtube. com/watch?v=eJZXJnFhEEI (accessed on 25 April 2019).

Nguyen, Han, and Brian H. Kleiner. 2003. The effective management of mergers. Leadership and Organization Development Journal 24: 447-54. [CrossRef]

NYU Stern. 2019. Natura Cosmeticos SA GARCH Volatility Analysis. V-Lab. Available online: https://vlab.stern. nyu.edu/analysis/VOL.NATU3:BZ-R.GARCH (accessed on 17 October 2019).

Osborne, J. David, Charles I. Stubbart, and Arkalgud Ramaprasad. 2001. Strategic groups and competitive enactment: A study of dynamic relationships between mental models and performance. Strategic Management Journal 22: 435-54. [CrossRef]

Penrose, Edith. 1959. A Theory of the Growth of the Firm. Oxford: Basil Blackwell.

Penrose, Edith, and Christos N. Pitelis. 2009. The Theory of the Growth of the Firm. Oxford: Oxford University Press, p. 665.

Prahalad, Coimbatore Krishnarao, and Gary Hamel. 1990. May-June. The core competence of the organization. Harvard Business Review, 79-93.

Ralph, Nicholas, Melanie Birks, and Ysanne Chapman. 2014. Contextual Positioning: Using Documents as Extant Data in Grounded Theory Research. SAGE Open 4: 1-7. [CrossRef]

Rugman, Alan M., and Alain Verbeke. 2002. Edith Penrose's contribution to the resource-based view of strategic management. Strategic Management Journal 23: 769-80. [CrossRef]

Sahu, Benudhar, and Indu Pereru. 2019. Natura's Acquisition of Avon Products. ICRM No. 319-0284-8. Hyderabad: IBS Center for Management Research.

Schipani, Andres. 2018. Body Shop Owner Natura Targets Global Growth. Financial Times, February 4. Available online: https://www.ft.com/content/d4c868a0-091b-11e8-8eb7-42f857ea9f09 (accessed on 17 October 2019).

Sekaran, Uma, and Roger Bougie. 2018. Research Methods for Business: A Skill-Building Approach. Chichester: Wiley, p. 448.

Sharma, Nilosha. 2016. Instagram: Exploring an Innovative Monetization Model. Bangalore: AMITY Research Centers Headquarter, pp. 1-12.

Siggelkow, Nicolaj. 2007. Persuasion with case studies. Academy of Management Journal 50: 20-24. [CrossRef]

Spanner, Gary E., José Pablo Nuño, and Charu Chandra. 1993. Time-based strategies-Theory and practice. Long Range Planning 26: 90-101. [CrossRef]

Straits Research. 2020. Available online: https://straitsresearch.com/blog/top-10-cosmetic-companies-in-theworld-2020 (accessed on 12 April 2020).

Strategic Management Society, and Strategy Practice IG. 2020. What Do We Do? Available online: https: //www.strategicmanagement.net/ig-strategy-practice/overview (accessed on 27 March 2020).

Teece, David J., Gary Pisano, and Amy Shuen. 1997. Dynamic capabilities and strategic management. Strategic Management Journal 18: 509-33. [CrossRef]

Trigeorgis, Lenos, and Jeffrey J. Reuer. 2017. Real options theory in strategic management. Strategic Management Journal 38: 42-63. [CrossRef]

Tsang, Eric W. K. 2013. Case study methodology: Causal explanation, contextualization, and theorizing. Journal of International Management 19: 195-202. [CrossRef]

Weber, Robert Philip. 1990. Basic Content Analysis. Newbury Park: Sage.

Witt, Ulrich. 2016. What kind of innovation do we need to secure our future? The Journal of Open Innovation: Technology, Market, and Complexity 2: 1-14. [CrossRef]

WorldGovernmentBond. 2019. Brazil 10 Years Bond-Historical Data. Available online: http://www. worldgovernmentbonds.com/bond-historical-data/brazil/10-years/ (accessed on 17 October 2019).

YahooFinance. 2019. Natura Cosmeticos S.A. (NATU3.SA). Available online: https://finance.yahoo.com/quote/ NATU3.SA/financials? $\mathrm{p}=$ NATU3.SA\&.tsrc=fin-srch (accessed on 17 October 2019).

Yin, Robert K. 1984. Case Study Research: Design and Methods. Newbury Park: Sage. 
Yin, Robert K. 2009. Case Study Research: Design and Methods, 4th ed. Newbury Park: Sage.

Zenger, Todd. 2016. Do M\&A Deals Ever Really Create Synergies. Harvard Business Review. Available online: https://hbr.org/2016/07/do-ma-deals-ever-really-create-synergies (accessed on 27 April 2020).

(c)

(C) 2020 by the author. Licensee MDPI, Basel, Switzerland. This article is an open access article distributed under the terms and conditions of the Creative Commons Attribution (CC BY) license (http://creativecommons.org/licenses/by/4.0/). 